\title{
To Evaluate The Efficacy of Amaranthus Viiridilis And Ferrous Sulpphate Capsules In Garbhini-Pandu W.S.R To Anaemia In Pregnancy.
}

\author{
${ }^{1}$ Dr . Tomar Pravesh, ${ }^{2}$ Dr.Lal Sudeep, ${ }^{3}$ Dr. Garg Saloni \\ 1. Associate Professor, Dept. of Prasuti Tantra \& Stri Roga. \\ Rishikul Campus, Haridwar, Uttrakhand Ayurveda University ,Harrawala ,Dehradun (India) \\ 2. Lecturer department of Swasthwritta, Swami Kalayan Dev Ayurvedic College, Mujjafarnagar. \\ 3. PG Scholar (M.S.2 ${ }^{\text {nd }}$ yr ), Dept. Of Prasuti Tantra \& Stri Roga. \\ Rishikul Campus, Haridwar, Uttrakhand Ayurveda University ,Harrawala ,Dehradun (India)
}

\begin{abstract}
-
Aims and objectives: To evaluate the efficacy of Tanduliyaka in the management of anaemia during pregnancy and compare its efficacy with the standard drug ferrous sulphate.

Material and methods :The present study was conducted in 30 clinically diagnosed patients of GarbhiniPandu i.e. Iron Deficiency Anaemia during pregnancy of 16 to 24 weeks gestational age (Hb\% 6-10gm\%, pallor in mucous membranes (Pandu), rough and dry skin (Raukshya), breathlessness (Swas), fatigue (Shram), palpitation(Hridspandan), oedema(Shoth), etc.) for clinical evaluation of amaranthus on the various Ayurvedic and scientific parameters. For this purpose Ghan Kalpna of Tanduliyaka, filled in capsules (500mg 1BD) was provided to 15 patients and they were asked to consume it with lemon water. Second group of 15 patients was treated with iron tablets (60mg 1OD).

Results :It was observed from the current research project that patients of Iron deficiency Anaemia in pregnancy treated with Tanduliyaka capsules in group-A, showed extremely significant $\operatorname{results}(\mathrm{P}<0.001)$ where as in group-B significant results were observed $(\mathrm{P}<0.01)$ in Haemoglobin\% and subjective parameters(Aruchi, Daurbalya, Hridayspandan, Swas, Pandu, Shoth).Only significant results appeared in other investigating parameters i.e. RBC PCV MCV etc. No side/toxic effects were noted in any patient and her foetus during the treatment and after completion of treatment. The outcome of labour was also good.

Conclusion: It can be concluded that Tanduliyaka Ghan capsule is a classical and potent haematinic drug which can be used effectively in the management of Garbhini Pandu vis a vis anemia in pregnancy.
\end{abstract}

\section{Keywords - Amaranthus viiridilis, Garbhini Pandu., Panduta, Daurbaly, Ghan Kalpna.}

\section{INTRODUCTION-}

Anaemia is defined as decreased total amount of RBCS or haemoglobin in the blood.1 It can also be defined as a lowered ability of blood to carry oxygen. Anaemia is classified in three type i.e due to decreased production of RBC (in Iron deficiency anaemia, B12 deficiency, thalassemia, and a number of neoplasms of bone marrow), second type is due to increased RBC breakdown (in sickle cell anaemia, some genetic and autoimmune diseases etc.), and third type of anaemia is due to loss of blood. ${ }^{2}$

Another classification is morphological (based on size and volume of RBC, reflected in MCV and may also be classified by haemoglobin content of RBC) and pathophysiological (Iron deficiency anaemia, megaloblastic, aplastic, haemolytic, nutritional deficiency, etc.).

Iron deficiency anaemia is summarised in three steps ${ }^{3}$ i.e. Depletion of iron stores, iron deficient erythropoiesis and finally iron deficient anaemia. So Iron deficiency anaemia is defined as microcytic hypochromic $(\mathrm{MCV}<80 \mathrm{fl})$ state secondary to total body iron deficit. Iron deficiency anaemia is based on concept of negative iron balance, iron stored depletion along with iron deficit erythropoiesis. Iron deficiency anaemia develops when body stores of iron drop too low to support normal red blood cell production. It is worthwhile to consider the steps by which iron deficiency occurs. 
In the first step, the demands for iron exceed the body's ability to absorb iron from the diet (pregnancy in which the demands for RBC production by foetus and growth needs of foetus outstrip the mother's ability to provide iron). The second step in this way, the iron deficit must be made up by mobilization of iron from reticulo-endothelial storage site. During this period iron store measurement (ferritin level or appearance of sustainable iron on bone marrow aspiration) will decrease. As long as the iron stores are present and can be mobilised the serum iron, total iron binding capacity, red cell protoporphyrin level remain within normal limits. In the third step when iron stores become depleted, the serum iron level begins to fall gradually, the total iron binding capacity increases as do red cell porphyrin level. Marrow iron stores are absent when serum ferritin level $<15 \mathrm{~g} / \mathrm{dl}$. As long as serum iron level remains normal Haemoglobin synthesis is unaffected .Once transferrin saturation falls to 15 to $20 \%$, haemoglobin synthesis becomes impaired. This is the period of iron deficient erythropoiesis.

Patient with Iron deficiency in pregnancy includes the conditions of:

\section{Subjective criteria:}

- Malaise (general weakness, early fatigue, lassitude, diminished capability to perform daily routine work, Ghabrahat, restlessness etc).

- Giddiness(sensation of whirling and a tendency to fall or stagger or dizziness)

- Abdominal discomfort

\section{Objective criteria:}

- Anorexia

- Breathlessness

- Dryness

- Palpitations

- Oedema.

ACOG recommends screening of all pregnant women for anaemia, treating those with Iron Deficiency Anaemia (which it defines as haematocrit level $<33 \%$ in the first and third trimesters and less than $32 \%$ in the second trimester) with supplemental iron with prenatal vitamins. ${ }^{4}$

When the haemoglobin $\%$ is $<9 \mathrm{gm} / \mathrm{dl}$ or haematocrit level $<27 \%$, women should be treated with an oral dose of $60-120 \mathrm{mg} /$ day of iron.

In keeping the basic doctrines relating to the cause of the disease, Ayurveda considers that due to Nidan Sevana the process of Pandu-Roga is commenced with the prakopa of all three Doshas in the Dhatus. While explaining the Samprapti, Acharya Vagbhatta mentioned that Panduroga is mainly concerned with vitiation of Pitta which in turn vitiates the Rakta, leading to the condition of Pandu Bhava (Raktalpta, Medalpta Nisarata,Vaivarnyata, Shithilendriya). Panduta is invariable feature. Aruchi, Pipasa, Jwar, Murdhruja, Shoph, Shoth, Swas, etc are described as Updrava of Pandu Roga.

According to Ayurveda Chikitsa of Garbhini Vyadhi should be done with Mridu, Shit ,Madhur, Ras Pradhan Aushdhi and planning is done for shaman chikitsa (palliative treatment) because samshodhan Chikitsa is avoided as per rule. So the treatment should be: according to predominance of doshas, lakshanas, PathyaApathya, specific treatment

\section{Aims And Objectives:}

1. To evaluate the efficacy of tanduliyaka in the management of anaemia during pregnancy.

2. To compare the efficacy of tanduliyaka in the management of anaemia during pregnancy with the standard drug ferrous sulphate.

\section{Materials And Methods:}

\section{Selection of Drug:}

Under nutrition and micro nutrients deficiencies are widespread and affect mainly women and children. To address these problems, increased consumption of leafy vegetables is promoted as sources of both micronutrients and bio active compounds. Amaranthus is one of the widely promoted leafy vegetables. Cooked amaranthus provides 25 calories and is an excellent source of protein, dietary fibres and some 
${ }^{1}$ Dr . Tomar Pravesh , International Journal of Ayurvedic \& Herbal Medicine 7(4) July.-Aug. 2017 (2763-2768)

dietary minerals. It is particularly rich in manganese, iron, magnesium and selenium. It also contains high concentration of folic acid.

\section{Administration Of Drug:}

The drug was administered to patients under two groups:

Group A: Total 15 patients are registered in this group and given Tanduliyaka capsules made from Ghan extract with Luke warm water.

Group B: Total 15 patients are registered in this group were treated with iron tablets

Duration of clinical trial: 90 days in both groups

\section{Follow-up:}

-All the patients were followed up after30, 60 and 90 days after starting treatment.

-Improvement/changes produced, if any and other effects produced were also noted down.

-Relevant laboratory investigations were repeated before and after completion of treatment.

\section{Selection of patients:}

Total 30 patients having anaemia during pregnancy were randomly selected from O.P.D. / I.P.D. Of dept. of Stri Evam Prasuti Tantra and C.R.W Hospital Haridwar, Uttrakhand .

\section{Inclusion criterias:}

Fulfilling the diagnostic criteria

Age group between 20-35 years

Gestational age between 16 weeks to 24 weeks

Primigravida

Haemoglobin below $10 \mathrm{gm} \%$ and above $6 \mathrm{gm} \%$

Blood picture with microcytic and hypochromic and normocytic hypochromic

\section{Exclusion criterias:}

Cases of anaemia other than iron deficiency anaemia like thalassemia, sickle cell anaemia, pernicious anaemia, etc.

Anaemia associated with bleeding piles and other bleeding disorders.

Multiple pregnancy

High risk cases of preeclampsia, gestational diabetes, metabolic disorders, diabetes, jaundice, etc

Other medical disorders

Drug allergy.

\section{Criteria of assessment:}

During the trial and follow-up study the subjects were assessed on the basis of the following parameters-

Subjective parameters - All the subjects registered for the present trial were asked for any changes in feeling of wellbeing i.e.Hatprabhatva (malaise ), Bhram (giddiness), Udarkshobh (abdominal discomfort). Clinical parameters- The following sign and symptoms are looked into to assess the improvement in both the groups during and after the course of the therapy -

anorexia (Aruchi), breathlessness(Swas), dryness(Raukshya) Palpitation (Hridspandan), pallor (Panduta). Physiological parameters-Temprature was measured in every follow-up in Fahrenheit. The variation was found between $98^{\circ} \mathrm{F}$ to $99^{\circ} \mathrm{F}$ which is normal during pregnancy due to the effect of progesterone hormone. Pulse rate were noted in different patients between 80 to 110 per minute which is the effect of palpitations and improvement in this variation was observed after the treatment. Respiratory rate was also noted per minute and stability was observed in breathlessness (increased rate of respiration) after the treatment. Blood Pressure was measured in $\mathrm{mm}$ of $\mathrm{Hg}$ and it was found variable in sitting, lying and standing position. The normal pressure was found to be decreased in standing position in cases of severe anaemia. After the therapy improvement was observed in this downfall of BP. Normal weight gain was observed in patients according to period of amenorrhoea. 
${ }^{1}$ Dr . Tomar Pravesh , International Journal of Ayurvedic \& Herbal Medicine 7(4) July.-Aug. 2017 (2763-2768)

Obstetric parameters- all the obstetric parameters (Fundal height, Foetal heart sound, daily fatal movement count, abdominal girth) were found within normal limits in every follow-up. Abdominal tenderness was found to be absent after the treatment.

Improvement in physiological and obstetric parameter was found same in both the groups. Some patient showed mild to moderate intolerance with ferrous sulphate tablets in terms of gastric trouble, constipation generalised pain in abdomen etc. which was managed successfully.

Pattern of lab investigations - Hb, RBC, MCV, PCV, urine routine and microscopic.

\section{OBERVATIONS AND RESULTS:}

Results of drug in single group are obtained by applying "paired t test" and comparative effect was evaluated by applying unpaired "t test" as shown in Table 1, Table 2, Table 3, Table 4.

Table 1. Quantitative Analysis Of Capsule Amaranthus On Group A

\begin{tabular}{|c|c|c|c|c|c|c|c|c|}
\hline $\begin{array}{c}\text { Parameters } \\
(\mathbf{n}=\mathbf{1 4})\end{array}$ & \multicolumn{2}{|c|}{ Mean } & $\mathbf{X}$ & $\boldsymbol{0}$ & $\mathbf{S D}$ & $\mathbf{S E}$ & "T" & P Value \\
\cline { 2 - 8 } $\begin{array}{c}\text { HAEMOGLOBI } \\
\mathbf{N}\end{array}$ & $8.073 \pm 1.089$ & $9.520 \pm 0.9435$ & 1.447 & 17.923 & 0.769 & 0.2056 & 7.036 & $<0.0001$ \\
\hline $\mathbf{R B C}$ & $2.733 \pm 0.457$ & $2.467 \pm 0.5164$ & 0.2667 & 9.759 & 0.4422 & 0.1182 & 2.256 & $<0.05$ \\
\hline $\mathbf{P C V}$ & $1.467 \pm 0.639$ & $1.533 \pm 0.5164$ & 0.06667 & 4.545 & 0.5736 & 0.1533 & 0.4350 & $>0.005$ \\
\hline MCV & $2.600 \pm 0.507$ & $2.400 \pm 0.5071$ & 0.2000 & 7.692 & 0.3990 & 0.1069 & 1.871 & $>0.005$ \\
\hline
\end{tabular}

Table 2. Qualitative Analysis Of Capsule Amaranthus On Group A

\begin{tabular}{|c|c|c|c|c|c|c|c|c|}
\hline $\begin{array}{c}\text { Parameter } \\
(\mathbf{n}=\mathbf{1 4})\end{array}$ & \multicolumn{2}{|c|}{ Mean } & $\mathbf{X}$ & $\mathbf{\%}$ & $\mathbf{S D}$ & $\mathbf{S E}$ & "T" & P Value \\
\cline { 2 - 9 } Panduta & $2.333+0.8165$ & $0.6667+0.4880$ & 1.667 & 71.453 & 0.6993 & 0.1869 & 8.991 & $<0.0001$ \\
\hline Daurbalya & $1.933+1.100$ & $0.6667+0.4880$ & 1.267 & 65.546 & 0.9286 & 0.2482 & 5.104 & $<0001$ \\
\hline $\begin{array}{c}\text { Hrid- } \\
\text { spandana }\end{array}$ & $1.333+0.8165$ & $0.4667+0.5164$ & 0.8667 & 65.019 & 0.6181 & 0.1652 & 5.245 & $<0.0001$ \\
\hline Rukshata & $1.200+1.146$ & $0.4000+0.5071$ & 0.8000 & 66.667 & 0.8325 & 0.2225 & 3.595 & $<0.01$ \\
\hline Aruchi & $0.4000+0.5071$ & 0.000 & 0.4000 & 40.000 & 0.4897 & 0.1309 & 3.055 & $<0.01$ \\
\hline Swasa & $1.467+1.246$ & $0.4000+0.6325$ & 1.067 & 72.73 & 0.8538 & 0.2282 & 4.675 & $<0.001$ \\
\hline
\end{tabular}

Table 3. Quantitative analysis of iron capsules on group B

\begin{tabular}{|l|l|l|l|l|l|l|l|l|}
\hline \multirow{2}{*}{ Parameter(n=14) } & Mean & X & \% & SD & SE & “t” & P value \\
\cline { 2 - 9 } & BT & AT & & & & & & \\
\hline Haemog-Lobin & $8.347 \pm 0.9927$ & $9.200 \pm 1.042$ & 0.8533 & 10.223 & 0.4531 & 0.1211 & 7.049 & $<0.001$ \\
\hline RBC & $2.667 \pm 0.4880$ & $2.267 \pm 0.4577$ & 0.4000 & 14.998 & 1.497 & 0.1309 & 3.055 & $<0.01$ \\
\hline PCV & $1.467 \pm 0.5164$ & $1.933 \pm 0.2582$ & 0.4667 & 31.813 & 0.499 & 0.1333 & 3.500 & $<0.01$ \\
\hline MCV & $2.600 \pm 0.5071$ & $2.467 \pm 0.5164$ & 0.1333 & 5.127 & 0.3401 & 0.0909 & 1.468 & $<0.05$ \\
\hline
\end{tabular}

Table 4.Qualitative analysis of iron capsules on group B

\begin{tabular}{|l|l|l|l|l|l|l|l|l|}
\hline \multirow{2}{*}{ Parameter(n=14) } & Mean & X & \% & SD & SE & “t” & P value \\
\cline { 2 - 8 } & BT & AT & & & & & & \\
\hline PANDUTA & $2.067 \pm 1.033$ & $1.600 \pm 0.7368$ & 0.4667 & 22.579 & 0.4988 & 0.1333 & 3.500 & $<0.01$ \\
\hline DAURBALYA & $2.400 \pm 0.7368$ & $1.600 \pm 0.9856$ & 0.800 & 33.33 & 0.5414 & 0.1447 & 5.527 & $<0.0001$ \\
\hline HRID-SPANDANA & $1.933 \pm 0.9612$ & $0.8000 \pm 0.7746$ & 1.133 & 58.614 & 0.8845 & 0.2364 & 4.795 & $<0.0001$ \\
\hline RUKSHATA & $1.533 \pm 1.060$ & $0.8000 \pm 0.77460$ & 0.7333 & 47.834 & 0.7719 & 0.2063 & 3.556 & $<0.01$ \\
\hline ARUCHI & $0.6000 \pm 0.5071$ & $0.6667 \pm 0.4880$ & 0.0667 & 11.111 & 0.5736 & 0.1533 & 0.4350 & $<0.05$ \\
\hline SWASA & $1.4671 \pm 1.642$ & $0.7333 \pm 1.100$ & 0.7333 & 0.4999 & 0.7719 & 0.2063 & 3.556 & $<0.01$ \\
\hline
\end{tabular}




\section{DISSCUSION-}

Multiple factors lead to iron deficiency anaemia (IDA) in pregnancy. Nutritional iron deficiency, underlying inflammatory conditions, physiological haemo-dilution and several other factors affecting haemoglobin and iron status in pregnancy, leads to difficulties in establishing a definitive diagnosis of iron deficiency anaemia in pregnancy. Iron deficiency anaemia is associated with increased maternal and perinatal morbidity and mortality and long term adverse effect in new born .According to Ayurveda the major nutrient part of our body is in the form of Ras Dhatu the very first Dhatu amongst Sapt Dhatu which is responsible for nutrition of rest of seven Dhatus of our body. During pregnancy, growth of fetus and preparation for lactation phase is also dependent on Ras Dhatu so the probability of Anulom Ksaya due to imbalance between demand and supply of Poshak Dhatu. That's why the next coming Dhatu i.e. Raktdhatu is affected first in this series. Ras pradoshaj vikar are also common in Garbhavastha due to desire of consumption of Amla, Lavan ,Katu Ras Pradhan meals excessively and practising Abhojan ,Pramit Bhojan and Dauhridawastha are the main causative factors for Pitta Prakop and Agnimandh leads to less nutritive Ras Dhatu and Raktalpta resulting in Garbhini Pandu.

The management of Garbhini Vyadhi is indicated by diet-management and drugs consisting of Mridu-Virya (mild potency), Madhur-Ras (sweet), Sheet (cold) and Madhur Vipak etc. and properties which are noncontrary to fetus. This implies that proper nutrition along with Pitta pacifying measures are the main stream of management in Ayurveda.

Thus Ayurvedic management with amaranthus, which consisting all the above mentioned properties is selected for the study. It is less expensive, Deepan Pachan ,Srotoshodhak, Vishaghn and Balya. It was administered with lemon water Anupan as the vehicle which enhances medicinal qualities of the drug and helps to reach the target Dhatu. Vitamin c is powerful enhancer of iron absorption from non-meat foods when consumed with meal.

In the present study Ghan preparation is preferred due to its higher therapeutic efficacy and decreased particle size so that absorption of drug will increase. Ghan kalpna also has long self-life (saviryta-avadhi).

Vital statistics-The present study has shown that majority of pregnant women belong to age group 18-25 yrs $(56.66 \%)$. Incidence of occupation revealed that about $50 \%$ of patients were of low socio-economic status. $56.66 \%$ were house wife. $36.66 \%$ were educated upto secondary education, $20 \%$ higher secondary, $10 \%$ were graduate and only $6.66 \% .36 .66 \%$ were having poor dietary habits and $33.33 \%$ having moderate diet. During Prakriti-Parikshan $43.33 \%$ patients were found with Vataj Pittaj and $33.33 \%$ patients were with Pittaj Kaphaj Prakriti.56.66\% were muslim .50\% belonged to urban habitat and $53.33 \%$ patients were having $\mathrm{Hb} \%$ level between 8-10 and these patients were having gestational age between 16-20 weeks, and rest of the patients had $\mathrm{Hb} \%$ between 6-8 and they were mostly having gestational age more than 20 weeks of pregnancy. 53.33\% patient's conjunctiva was of pale colour. Maximum 50\% patients were having weight between $30-45 \mathrm{~kg}$. $46.66 \%$ pateints was having regular bowel habit and $43.33 \%$ were facing constipation. $53.33 \%$ patients Vyayamsakti was madhyam and $40 \%$ patients was awar.70\% patients were facing different type of stressful life.73\% patients were not doing any type of regular exercise. About $62 \%$ patients were having Mridu and Madhyam Koshth. Only $16 \%$ cases were having Samagni rest were suffering from Vishmagni. $46.66 \%$ cases felt difficulty in sleeping. Only $16.66 \%$ cases were living sedentary life .During analysis of Pradhan-Lakshans, Panduta found in 30\%, Daurbalya in 26.66\%, Hridspandan in10\%, Swas in $3.33 \%$, Aruchi in 20\%. Majority (60\%) of patients with $\mathrm{Hb} \%<7$ were also complaining of mild to moderate lower abdominal pain during movement. Shoth was noted in $40 \%$ subjects. When lab investigation were obsevered ,the erythrocyte count was less than 4.2 million in $66.66 \%$ patients, packed cell volume was less than $33 \%$ in $53.33 \%$, MCV was observed less than $70-90 \mathrm{cu} /$ cell in $66.66 \%$ patients .On clinical examination the pulse rate was found between 90-110 per minute in $66.66 \%$, volume of pulse varied between low and good, rhythm was observed regularly irregular with ectopic beats also in $50 \%$ pt . Blood pressure was reported between 100/60-110/70 in 56.66\% cases. Postural hypotension was observed in $33.33 \%$ patients during per abdominal examination fundal height was normal according to period of amenorrhea of the patients and FHS was between normal range ie140- 160 per minute. Daily foetal movements count was with in normal limits when it was asked to the patients. 
Subjective improvement- Group-A treated with Tanduliyak (amaranthas) capsules showed extremely significant results $(\mathrm{p}<.001)$ in subjective symptoms like Panduta and Daurbalya and significant results seen in group - $\mathrm{B}(\mathrm{p}<0.01)$. In case of Aruchi, relief was found very significant in group-A. This is may be due to high protein and complex carbohydrate present in amaranthus. Hridspandan and Swas were relieved in both groups.

Clinical improvement- At every regular clinical check-up the instability in vital measurement like increased Respiratory rate, irregularity in $\mathrm{P} / \mathrm{R}$ and minimal increment in body weight etc. were found to be improved significantly. Improvement in lower abdomen pain and tenderness was also noted. Awar Vyayam Sakti improved to be Madhyam. Emotional status was also seen well in patient with stress and malaise.

Laboratory parameters- $17.923 \%$ increase was found in Haemoglobin after 3 month tanduliyak (amaranthus) capsule treatment which is highly significant $(\mathrm{p}<0.001), 9.75 \%$ increase was found in RBC,7.69\% increase in $\mathrm{MCV}, 4.54 \%$ reduction was found in PCV in group-A. In group-B iron tablets were administered.

No abnormalities were observed in growth and development of intrauterine foetus and in any other physiological factors of pregnancy. This finding are suggestive of that Tanduliyak (amaranthus) is not only rich in iron but also is a good nutrient for pregnancy.

Thus on the basis of various observations recorded pn different parameters it is obvious that capsule tanduliak is potent and classical Raktadhatuposhak Aushadhi which is capable of producing statistically significant improvement in the patients of Garbhini Pandu viv a vis anaemia pregnancy. Thus capsule Tanduliyak possesses Rakta Dhatu Poshak effect.

All the patient tolerated the Tanduliyak (amaranthus) capsules very well and no side or toxic effect were reported by any of the subjects registered in the current series of 30 patients of IDA in pregnancy. Subjects of IDA in pregnancy suggesting thereby that capsule Tanduliyak (amaranthus) is absolutely safe in pregnancy.

\section{Probable mode of action}

Result showed statistically significant improvement in both subjective and objective parameters the effect of drug leads to improvement of metabolism, RBCs production, minerals consumption in body and relief from the disease. Amaranthus is Madhur in Rasa and Laghu Ruksh in Guna with Shita and Atishit in Veerya and Madhur Vipak. Due to these properties the drug becomes helpful in the treatment of Pandu is a Pittaj Vyadhi and the properties of amaranthus are Pittashamak. There is presence of other minerals in the drug has is iron content, folic acid along with some other mineral contents like $\mathrm{Ca}, \mathrm{Na}$, $\mathrm{K}$ Chromium, Magnesium content in it which are very useful in Garbhiniya Pandu for maintaining general health of mother and foetus.

CONCLUSION : From the present trial it has been observed on various scientific parameters that Tanduliyaka Ghana capsules seems to correct anaemia during pregnancy and it tends to improve Aruchi(anorexia), Daurbalya (generalised weakness), Raukshaya (dryness), Swas (breathlessness), Hridspandan (palpitations), Udarkshobh(abdominal discomfort), and maintains the feeling of wellbeing of pregnant patients, which are suggestive of Deepan, Pachan, Rasayan and Rakta Dhatu Poshak Prabhav of Tanduliyaka (amaranthus viridilis), thus the drug Tanduliyaka Ghan capsules possesses Potent Dhatu Poshak (haematinic) effect (correction of anaemia I.e. HB\%) in Garbhini Pandu (IDA in pregnancy) in accordance to both in Ayurvedic and modern medical parameters. Thus it can be concluded that Tanduliyaka Ghan capsules is a classical and potent haematinic drug which can be used effectively in the management of Garbhini Pandu vis a vis anemia in pregnancy.

\section{REFERENCES :}

1. Sonyam; Physiology Posts The Circulatory System. Function And Synthesis Of $\mathrm{Hb}$. Www.Interactive Biology.Com /3955

2. Stedman's Medical Dictionary (28th) Edition Philadelphia: Lipincott Williams And Wilkins.2006.p.Anaemia.Isbn 9780781733908

3. Accessmedicine. Mhmedical.Com./Content.Aspx? Bookid=1130 \& Sectioned $=79722272$ American Congress Of Obstetrics And Gynaecology Acog Practice Bulletin No, 95 Anemia In Pregnancy. Obstet Gynecol 2008; 112:201-7[Pubmed Absract] 